\title{
BIOSORPTION OF Ni (II) IONS BY ARABICAN COFFEE FRUIT (Coffea arabica)
}

\author{
Serly Tandigau ${ }^{1 *}$, Nursiah La Nafie ${ }^{1}$, Prastawa Budi ${ }^{1}$ \\ ${ }^{1}$ Department of Chemistry, Faculty of Mathematics and natural Sciences, Hasanuddin University, \\ Tamalanrea Makassar 90425
}

\begin{abstract}
Abstrak. Kulit buah kopi arabika merupakan material yang melimpah dan murah. Material ini telah digunakan sebagai adsorben dalam proses biosorpsi untuk penghilangan ion logam $\mathrm{Ni}$ (II) dari limbah cair. Biosorpsi ion logam $\mathrm{Ni}$ (II) oleh kulit buah kopi arabika dilakukan pada variasi ukuran partikel, waktu kontak, pH dan konsentrasi. Kapasitas adsorpsi ion Ni(II) oleh kulit buah kopi ditentukan dengan menggunakan isotermal adsorpsi Langmuir dan Freundlich. Konsentrasi ion logam $\mathrm{Ni}$ (II) sebelum dan setelah adsorpsi ditentukan dengan menggunakan Spektrofotometer Serapan Atom (SSA). Hasil penelitian menunjukkan bahwa waktu optimum yang diperoleh adalah 50 menit dan $\mathrm{pH}$ optimum adalah 6 dengan menggunakan ukuran partikel 120 mesh. Dari hasil penelitian ini diperoleh bahwa biosorpsi ion logam $\mathrm{Ni}$ (II) dengan menggunakan kulit buah kopi arabika sesuai dengan model isotermal Langmuir dengan nilai kapasitas biosorpsi (Qo) yakni sebesar 18,86 mg/g. Gugus fungsi yang terlibat dalam biosorpsi ion logam Ni(II) oleh kulit buah kopi adalah gugus hidroksil (-OH).
\end{abstract}

Kata Kunci: Biosorpsi, SSA, Isotermal Adsorpsi, Ni(II), Kulit Buah Kopi Arabika

ABSTRACT. Arabica coffee fruit peel is a material that is abundant and cheap. The material has been used as an adsorbent in the biosorption process for the removal of metal ions of $\mathrm{Ni}$ (II) from wastewater. Biosorption of $\mathrm{Ni}$ (II) ion by dragon fruit peel was done on the variation of particle size, variation of contact time, $\mathrm{pH}$ and concentration. Adsorption capacity was studied by both isotherm adsorptions of Langmuir and Freundlich. The concentration of metal ions Ni(II) before and after adsorption was determined using Atomic Absorption Spectrophotometer (AAS). Results showed that the optimum time was 50 minutes and the optimum pH was 6 with 120 mesh of particle size of biosorption. Results showed that the biosorption of $\mathrm{Ni}$ (II) ion using Arabica coffee fruit peel fullfilled the isotherm Langmuir model with the biosorption capacity (Qo) of 18.86 $\mathrm{mg} / \mathrm{g}$. The functional group involved in metal ion biosorption of $\mathrm{Ni}(\mathrm{II})$ by the peel of coffee fruit is a hydroxyl group $(-\mathrm{OH})$.

Keyword: Biosorption, AAS, Adsorption Isotherm, Ni(II), Arabica Coffee Fruit Peel.

\section{INTRODUCTION}

The rapid growth of the world population and the rapid development of the industry has caused more toxic waste materials to be thrown into the environment. These waste materials will later become waste and pollute the environment in an amount that is difficult to control properly. Pollutants are dominated by heavy metal waste, one of which is Nickel (Tangio, 2013).

Nickel (Ni) is one of heavy metals, which is widely used in kitchen equipment (spoons and cooking utensils), house and building ornaments, and industrial components. Apart from being an essential metal, nickel also has a dangerous effect (Axtell et al., 2003). Nickel is more toxic to plants. The nickel 
threshold in drinking water is $0.04 \mathrm{mg} /$ L (Suhendrayatna, 2001). Basically heavy metals in waste water can be separated in various ways, namely physical and chemical methods (Wisjnuprapto, 1996 in Soeprijanto et al., 2005). Physical processing is generally carried out by adsorption for example with activated carbon and membrane filtering. Other methods are used such as oxidation / reduction, ion exchange, filtration, evaporation, reverse osmosis and extraction. But these techniques or methods have deficiencies such as imperfect metal binding, require a lot of chemicals and energy, and produce toxic sediment and water products as a by-product (Vierra and Volesky, 2000). Whereas biological processing or biosorption is done by utilizing the ability of heavy metal accumulation by microorganisms (Soeprijanto et al., 2005).

Biosorption is an alternative to absorb heavy metals due to the presence of biological material components that have a large binding capacity (Kratochvil et al., 1998 in Nova et al., 2012). Biosorption is the process of absorption of analytes by biomass. Biosorption utilizes the ability of biological materials to accumulate heavy metals from solutions metabolically or physically-chemically (Diantariani et al., 2008).

Some biomaterials have the potential to absorb heavy metals generally from agricultural wastes. Aslam et al. (2010) prove that peepal leaves (Ficus Religiosa) which contain carboxylic, hydroxyl, and amino groups can bind Nickel metal. In 2010, Raj et al. Proved that amino acids from Moringa seeds can adsorb Ni (II) ions. Hasar (2002) reported that mangrove stem skin containing polysaccharides, lignin, polyphenols, and hydroxide acid has also been proven to absorb $\mathrm{Cu}$ (II) and $\mathrm{Ni}$ (II) ions. Watermelon skin which has the content of pectin, cellulose and protein is capable of being adsorbent of $\mathrm{Ni} 2+$ and $\mathrm{Co} 2+$ metals (Lakshmipathy and sarada, 2013).

The results of these studies indicate that agricultural waste containing functional groups can be further processed as an adsorbent that can be used to absorb heavy metals from the waters. The skin of Arabica coffee (Coffea arabica) is an agricultural waste that has a very large presence. In coffee plantations, solid waste of coffee fruit skin has not been used optimally.

Coffee skin is a by-product of harvest which has been a waste and is only used as organic material and animal feed (Budiari, 2014). Nuraini (2012) in Disafitri (2012) revealed that the skin of Arabica coffee fruit contains cellulose, and lignin which has the potential to bind heavy metals such as nickel metal from solution. The compounds contained in the skin of Arabica coffee fruit contain $\mathrm{OH}$ and $-\mathrm{COOH}$ groups. The active groups when viewed from Hard Soft Acid Base (HSAB) are classified as hard bases while $\mathrm{Ni}$ (II) metals are categorized as borderline acids.

\section{MATERIALS AND METHODS}

Research Materials 
The materials used in this study were Arabica (Coffea arabica) coffee skin, Ni (NO3) 2.6H2O, aquades, Whatman 42 filter paper, ordinary filter paper, label paper, and universal $\mathrm{pH}$.

\section{Research Tools}

The tools used in this research are glass tools commonly used in laboratories, Atomic Absorption Spectrophotometer (SSA) 205 VGP models, analytic balance, ovens, magnetic stirrers, sieves size 60, 80, 120 and 150 mesh, stopwatch, desiccator and spectrophotometer FT-IR Shimadzu prestige 21 .

\section{PROCEDURE}

\section{Preparation of Arabica Coffee Skin Biosorbent (Coffea arabica)}

The skin of Arabica coffee fruit that has been taken is washed with clean water to remove dirt and other particles. Then the skin of Arabica coffee is washed again with distilled water until clean and then drained. Coffee skin is dried at room temperature. The dried Arabica coffee skin is then milled and sieved with variations of filters 60,80 , 120 and 150 mesh. Clean Arabica coffee skin powder stored in an oven 80 oC for 24 hours then stored in a desiccator before weighing.

\section{Making Ni (II) $100 \mathrm{mg} / \mathrm{L}$}

Raw Solution For the manufacture of a standard solution of $\mathrm{Ni}$ (II) $1000 \mathrm{mg} / \mathrm{L}$ carried out by means of $\mathrm{Ni}(\mathrm{NO} 3) 2.6 \mathrm{H} 2 \mathrm{O}$ weighed as much as 4.9564 grams, then dissolved with aquabides to volume $1 \mathrm{~L}$. Furthermore, the standard solution of $\mathrm{Ni}$ (II) $1000 \mathrm{mg}$ / L was pipetted $100 \mathrm{~mL}$ and diluted to volume $1 \mathrm{~L}$ to make a standard solution of $100 \mathrm{mg} / \mathrm{L}$.
Determination of the effect of particle size on biosorption of $\mathrm{Ni}$ (II) ions by the skin of Arabica coffee (Coffea arabica)

Arabica coffee fruit skin powder with variations in size of 60 mesh, 80 mesh, 120 and 150 mesh inserted as much as 0.2 grams into 4 erlenmeyer pieces of size $100 \mathrm{~mL}$, then inserted 50 $\mathrm{mL}$ of $\mathrm{Ni}$ (II ) with a concentration of $100 \mathrm{mg} / \mathrm{L}$ at $\mathrm{pH}$ 5.1. The mixture is stirred for 10 minutes then filtered and the filtrate is collected to measure the levels of Ni (II) with AAS. The levels of $\mathrm{Ni}$ (II) in $\mathrm{Ni}$ (II) solution before adsorption were also measured. Each experiment is conducted in duplicate. The blank experiment is carried out as above.

Determination of Optimum time Biosorption of Ni (II) Ions by Arabica Coffee Fruit Skin (Coffea arabica)

Clean and dry Arabica coffee bark powder is 0.2 grams each into 10 $100 \mathrm{~mL}$ Erlenmeyer flasks and $50 \mathrm{~mL}$ of $\mathrm{Ni}$ (II) solution with a concentration of $100 \mathrm{mg} / \mathrm{L}$ and be shaken using a magnetic stirrer for $10,15,20,30,40$, $50,60,70,80$, and 90 minutes. Then the mixture is filtered and the filtrate is collected to measure the nickel content $(\mathrm{Ni} 2+)$ with SSA. Each experiment was repeated two times. The blank experiment is carried out as above but without stirring. The optimum time is where the concentration of adsorption (Cadsorption) is greatest.

Determination of Optimum $\mathbf{p H}$ Biosorption of Ni (II) Ion by Arabica Coffee Fruit (Coffea arabica)

0.2 grams of Arabica (Coffea arabica) coffee powder is added to 50 $\mathrm{mL}$ of $\mathrm{Ni}$ (II) metal ions with a concentration of $100 \mathrm{mg} / \mathrm{L}$ at $\mathrm{pH}$ 2. The mixture is shaken during the optimum time and filtered. The filtrate absorbance 
was measured by AAS. The experiment was repeated with different $\mathrm{pHs}$ of 3,4 , 5, 6 and 7. The blank experiments were carried out as above but without agitation. The optimum $\mathrm{pH}$ is $\mathrm{pH}$ where the greatest adsorbed concentration (Cadsorption).

\section{Determination of Biosorption} Capacity of Ni (II) Ions by Arabica Coffee Fruit Skin (Coffea arabica) Clean and dry Arabica coffee peel powder is 0.2 grams each into 6 Erlenmeyer sizes of $100 \mathrm{~mL}$, then $50 \mathrm{~mL}$ of a solution of $\mathrm{Ni}$ (II) metal ions with a concentration of 50, 100, 150, respectively. 200, 250 and $300 \mathrm{mg} / \mathrm{L}$. The mixture is shaken during the optimum time and $\mathrm{pH}$, then filtered and the filtrate is collected to measure the nickel content $(\mathrm{Ni} 2+)$ with AAS. The levels of $\mathrm{Ni}$ (II) in $\mathrm{Ni}$ (II) solution before adsorption were also measured. Done in duplicate. The blank experiment is done as above but without shuffling.
Biosorbent of Arabica coffee fruit skin before and after adding with $\mathrm{Ni}$ (II) solution concentration of $100 \mathrm{mg} / \mathrm{L}$ with optimum $\mathrm{pH}$ and time and dried at $50 \mathrm{oC}$ then analyzed with FT-IR (Fourier Transform Infra Red). The sample is smoothed with $\mathrm{KBr}$ in mortar using a mass ratio of 1:10. The results of the mixture are put into a special spherical place and then mixed to release water. The mixture is pressed for a moment $(10$ minutes) at a pressure of 72 Torr ( 8 to 20 tons per unit area) to produce thin circles. Readings of IR data spectra using the Grams Research software.

\section{RESULTS AND DISCUSSION}

\section{Effect of Particle Size on the Ni (II) Ion Biosorption by Arabica Coffee Fruit (Coffea arabica)}

Figure 1 shows that the number of $\mathrm{Ni}$ (II) metal ions absorbed by 60 mesh particle size is $13.06 \mathrm{mg} / \mathrm{g}$. This number continues to increase along with the smaller particle size given. At 120 mesh particle size the number of $\mathrm{Ni}$ (II) ions adsorbed was $16.51 \mathrm{mg} / \mathrm{g}$.

\section{FT-IR Analysis}

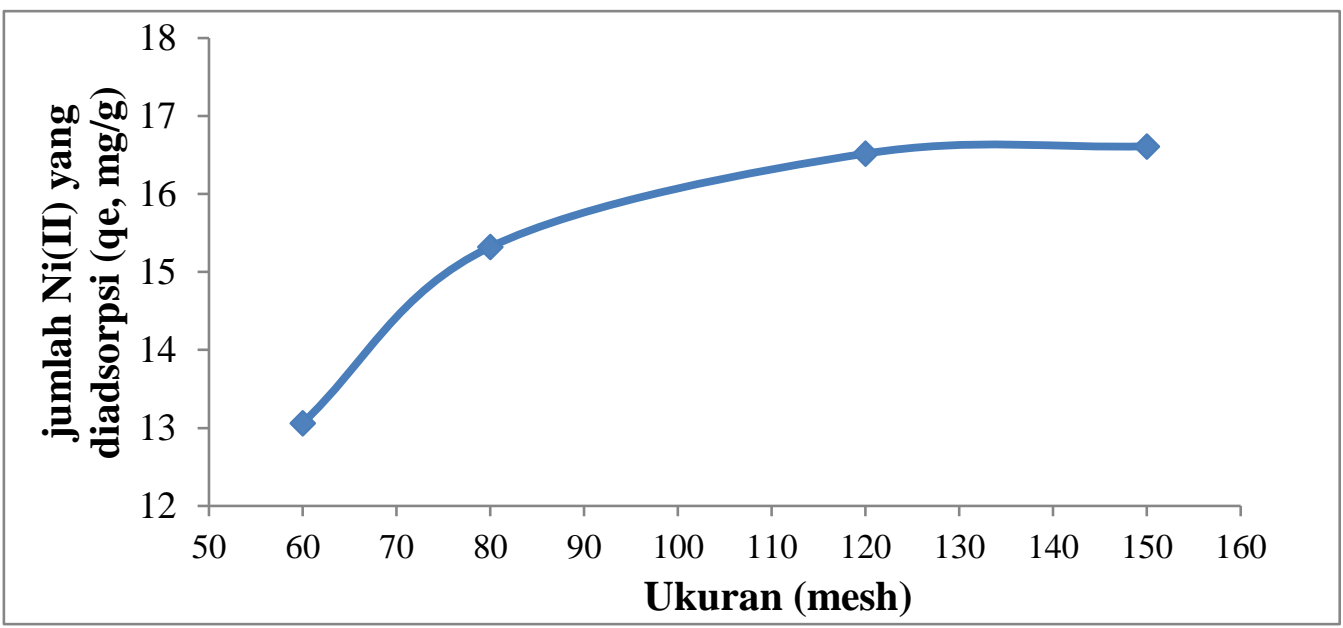

Figure 1. Effect of particle size on the amount of $\mathrm{Ni}$ (II) ions adsorbed by the skin of Arabica coffee fruit.

Furthermore, the coffee skin biosorption capacity at 150 mesh absorption was $16.61 \mathrm{mg} / \mathrm{g}$. Testing on small coffee fruit skin particle size causes high absorption of Ni metal. This happens because the smaller the size of the coffee fruit skin 
particles, the more dissolved material is filtered, so that the anion and cation content reacts more quickly with the metals contained in the adsorbent (Nurhayati, 2011 in Wibowo, A and Ardian, P., 2013 )

The smaller the diameter size of the adsorbent, the greater the reduction in the level of $\mathrm{Ni}$ (II). This is because the smaller the diameter size of the adsorbent means the contact surface area between the adsorbent and the Ni (II) metal ion is greater. In addition, the surface area is also directly proportional to the number of pores that are owned per Based on Figure 2 it can be seen that the amount of $\mathrm{Ni}$ (II) ions absorbed at minute 10 is $14.53 \mathrm{mg} / \mathrm{g}$. This amount continues to increase until it reaches the optimum limit with the amount of ion adsorbed at $16.12 \mathrm{mg} / \mathrm{g}$ in the 50th minute. The adsorption ability of Ni (II) metal drops to near the saturation point after passing 50 minutes. This condition is in accordance with the theory that the longer the contact time between the unit of particle adsorbent (Aji, et al, 2012).

Based on the amount of absorption effectiveness which shows the absorption percentage for size 120 with 150 which the percentage difference is very small. Further research used 120 mesh particle size with a capacity of $16.51 \mathrm{mg} / \mathrm{g}$, in addition to facilitating the screening process to avoid aggregation events.

\section{Effect of Optimum Biosorption Time of Ni (II) Ion by Arabica Coffee Fruit (Coffea arabica)}

adsorbent and the solute, the more dissolved substances will be adsorbed. However, the amount of adsorbed solute will reach the optimum limit at a certain time. This shows that the active side of the surface of the coffee fruit skin is saturated. The decrease in adsorption capacity after the optimum time can also be caused by the desorption process which shows reversible adsorption (Ekmekyapar, et al, 2006).

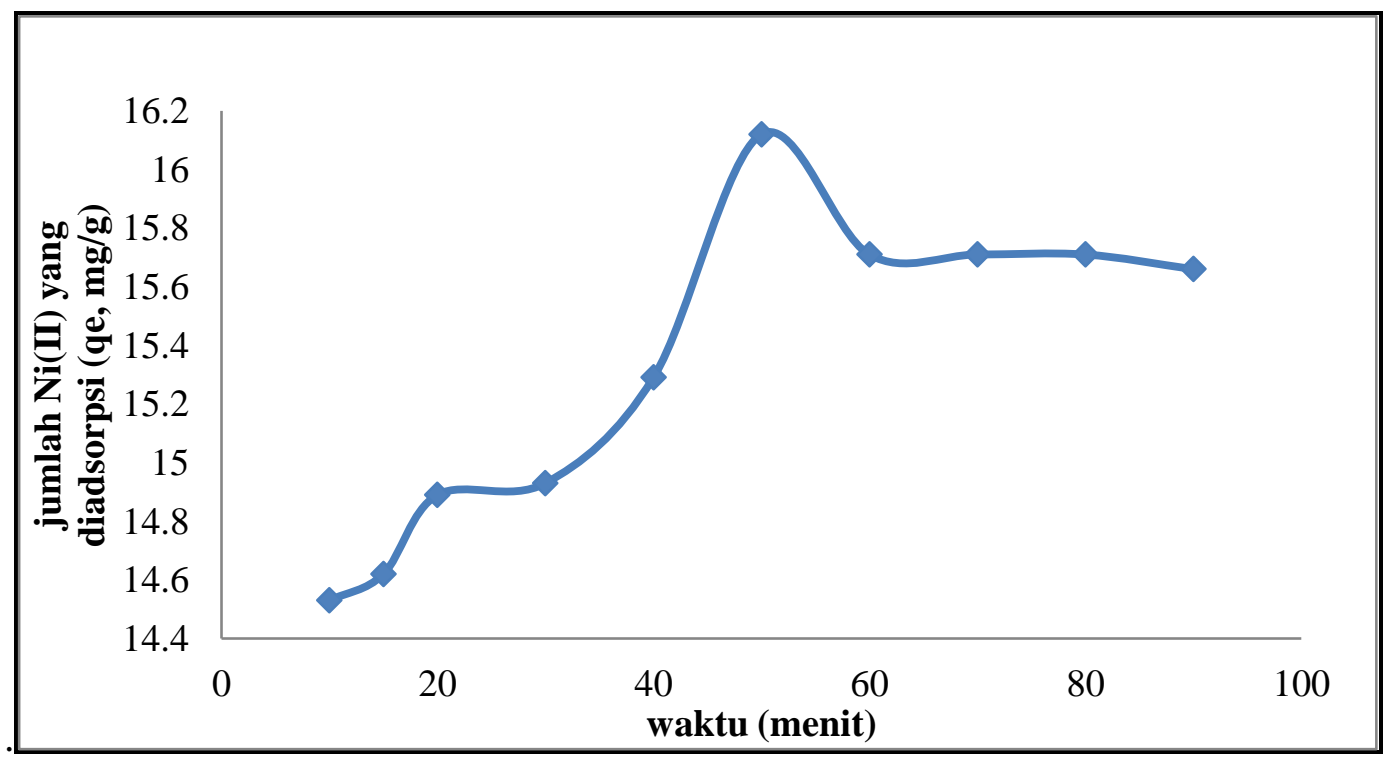

Figure 2. Effect of contact time on the adsorption capacity of $\mathrm{Ni} 2+$ ions by the adsorbent of Arabica Coffee fruit skin.

The same was reported by Effendi (2015) who used activated rice husk charcoal to adsorb $\mathrm{Ni}$ (II) and $\mathrm{Pb}$
(II) metals. Where the optimum contact time at 50 minutes Amaliah et al. (2012) in the study of coral utilization as 
biosorbent, Ni (II) metal ions obtained an optimum time of 90 minutes. Krishna and Swamy (2011) in the Ni (II) metal adsorption study using papaya seeds obtained contact time of 90 minutes. Abbasi, et al. (2013) obtained optimum contact time of 30 minutes in the study of absorption of $\mathrm{Co} 2+$ and $\mathrm{Ni} 2+$ metals from waters using banana peels. The optimum contact time for $\mathrm{Ni}$ (II) biosorption of metals in several studies showed different results, depending on the type of biosorbent

\section{Effect of pH on the absorption of $\mathrm{Ni}$ (II) ions by Arabica coffee fruit skin (Coffea arabica)}

Determination of optimum $\mathrm{pH}$ was carried out to determine the $\mathrm{pH}$ of the interaction where biosorbent absorbed $\mathrm{Ni}$ (II) to the maximum

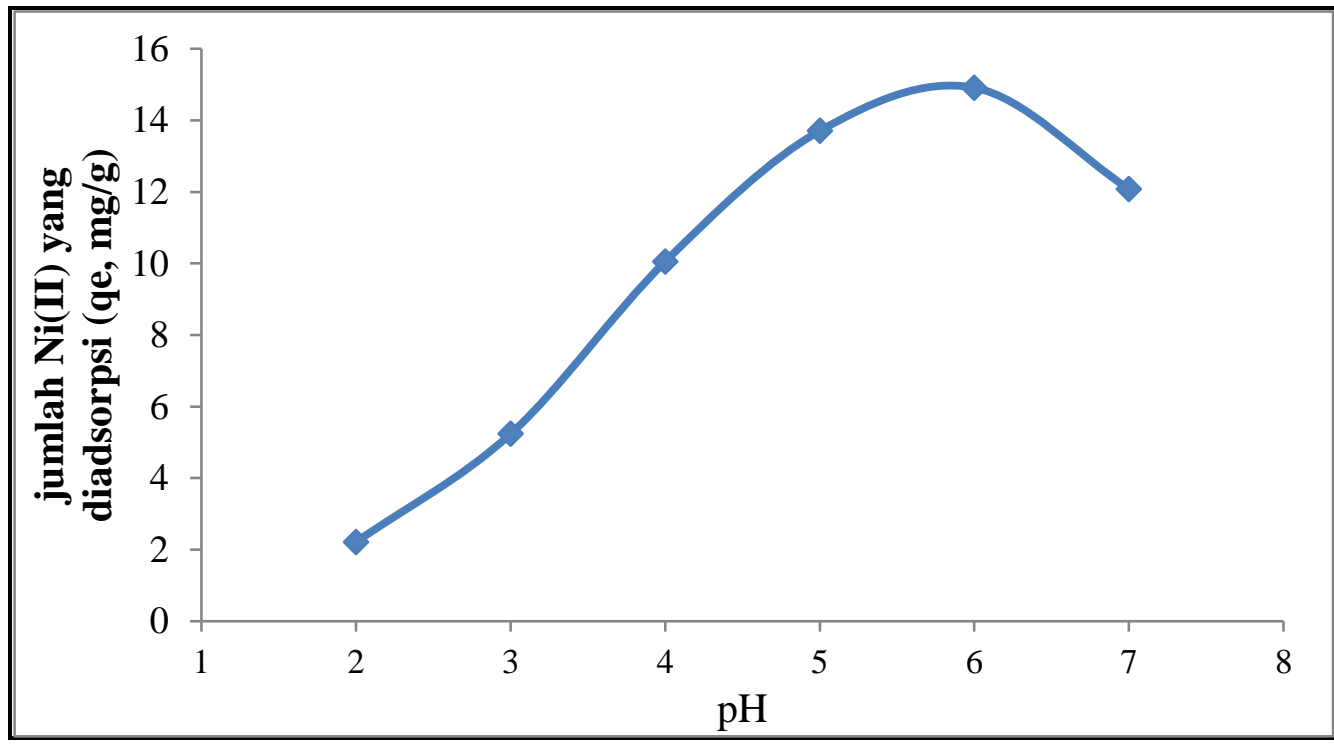

Figure 3. Effect of $\mathrm{pH}$ on the adsorption capacity of $\mathrm{Ni} 2+$ ions by the adsorbent of Arabica Coffee fruit skin.

Figure 3 shows that at a low $\mathrm{pH}$ the amount of $\mathrm{Ni}$ (II) ions adsorbed by coffee fruit peels is very small at $2.21 \mathrm{mg}$ / g. This is because at low $\mathrm{pH} \mathrm{H}+$ ions compete with $\mathrm{Ni} 2+$ metal cations to bind to active groups on the adsorbent (Ahmad et al., 2009). This amount continues to increase until it reaches the optimum limit with the amount of adsorbed ion amounting to $14.91 \mathrm{mg} / \mathrm{g}$ at $\mathrm{pH}$ 6. The increase in this increase is due to the greater $\mathrm{pH}$, the active groups of adsorbents are deprotonated and have a negative charge ie $\mathrm{OH}$ - ion which is very reactive to metals so that the adsorbed metal gets bigger. At $\mathrm{pH} 7$ the concentration of adsorbed $\mathrm{Ni}$ decreases. This is probably due to the fact that there is an equilibrium in the active site of the biomass with metal ions and this condition is probably due to sedimentation. $\mathrm{Ni}$ (II) ions form deposits with $\mathrm{OH}$ - ions in the form of $\mathrm{Ni}(\mathrm{OH}) 2$ bonds. As a result of this precipitation, the $\mathrm{Ni}$ (II) ions present in the solution are reduced so that the amount adsorbed also decreases. The same was reported by Amaliah, in a study of coral utilization as biosorbent of metal ion $\mathrm{Ni}$ (II) with maximum adsorption capacity at $\mathrm{pH}$ 6. The use of activated charcoal from coffee bean skin to adsorb dyes Methylene blue was also optimal at $\mathrm{pH} 6$ and Naphthol yellow optimal at $\mathrm{pH} 2$ (Purnomo, 2010). Mildayati (2009) reported the optimum biosorption of $\mathrm{Ni}$ 
(II) metal at $\mathrm{pH} 5$ using sago pulp. Malimongan (2015) reported the use of cocoa peel as biosorbent of Ni (II) metal ions with optimum adsorption capacity at $\mathrm{pH}$ 5. This is in accordance with that reported by Shofiyani and Gusrizal (2006) that the adsorption of $\mathrm{Ni}$ (II) occurs optimally in a wide range of acidic media which is at pH 5-9.

Because the amount of Ni (II) ions adsorbed by the skin of Arabica (Coffea arabica) coffee fruit is maximum at $\mathrm{pH} 6$, further research to determine the adsorption capacity is carried out at that $\mathrm{pH}$.

\section{Adsorption Capacity of Ni (II) Ions by Arabica Coffee Fruit Skin(Coffea arabica).}

The picture above shows that the higher the concentration, the greater the number of Ni (II) ions adsorbed by the coffee fruit peels and then tends to remain caused by biosorbents which have experienced saturation. This is as reported by Amini (2008) and Dilek (2001), which states that the number of metal ions adsorbed by biosorbents will increase with increasing concentration of a solution as long as the bond side is not.

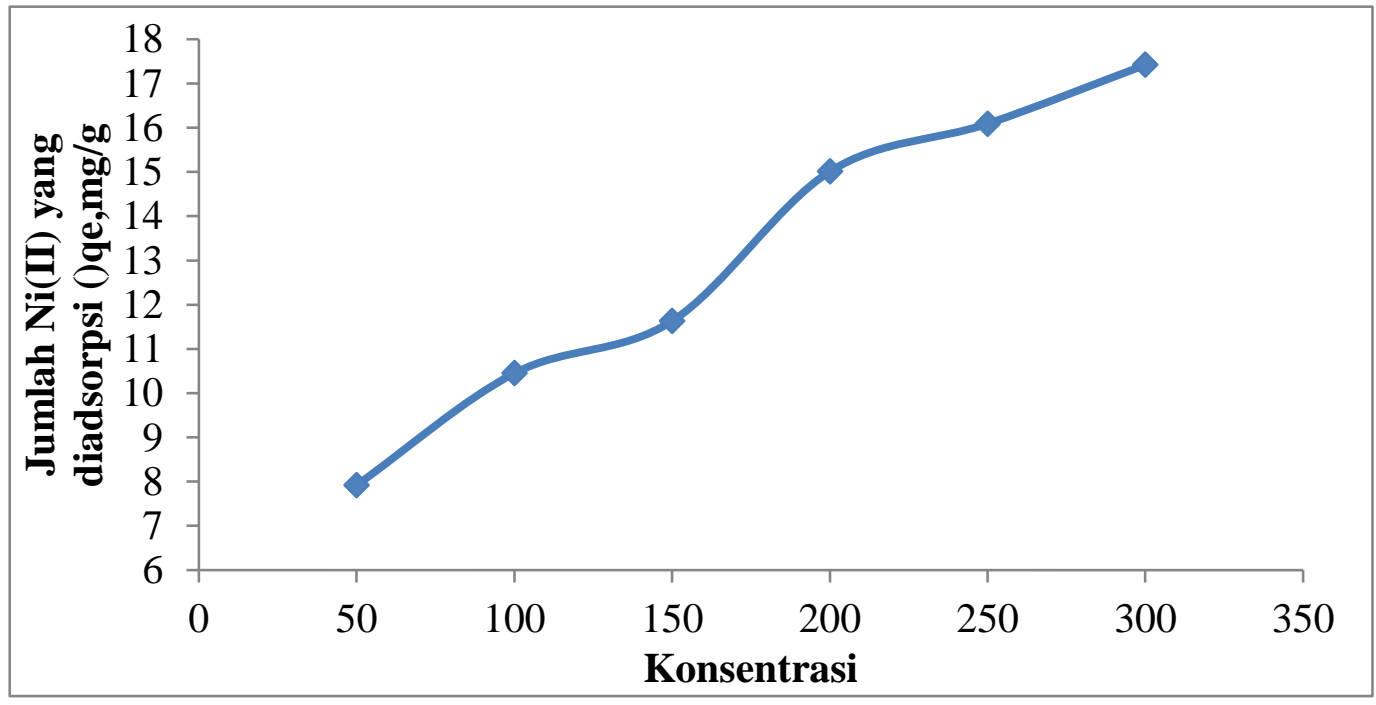

Figure 4. Number of $\mathrm{Ni}$ (II) ions adsorbed as a function of concentration at 50 minutes and $\mathrm{pH} 6$.

To determine the biosorption capacity of $\mathrm{Ni}$ (II) ions by the skin of Arabica Coffee (Coffea arabica) fruit, the Langmuir equation and the Freundlich equation were used. The 
results can be seen in Figure 5 and Figure

6.

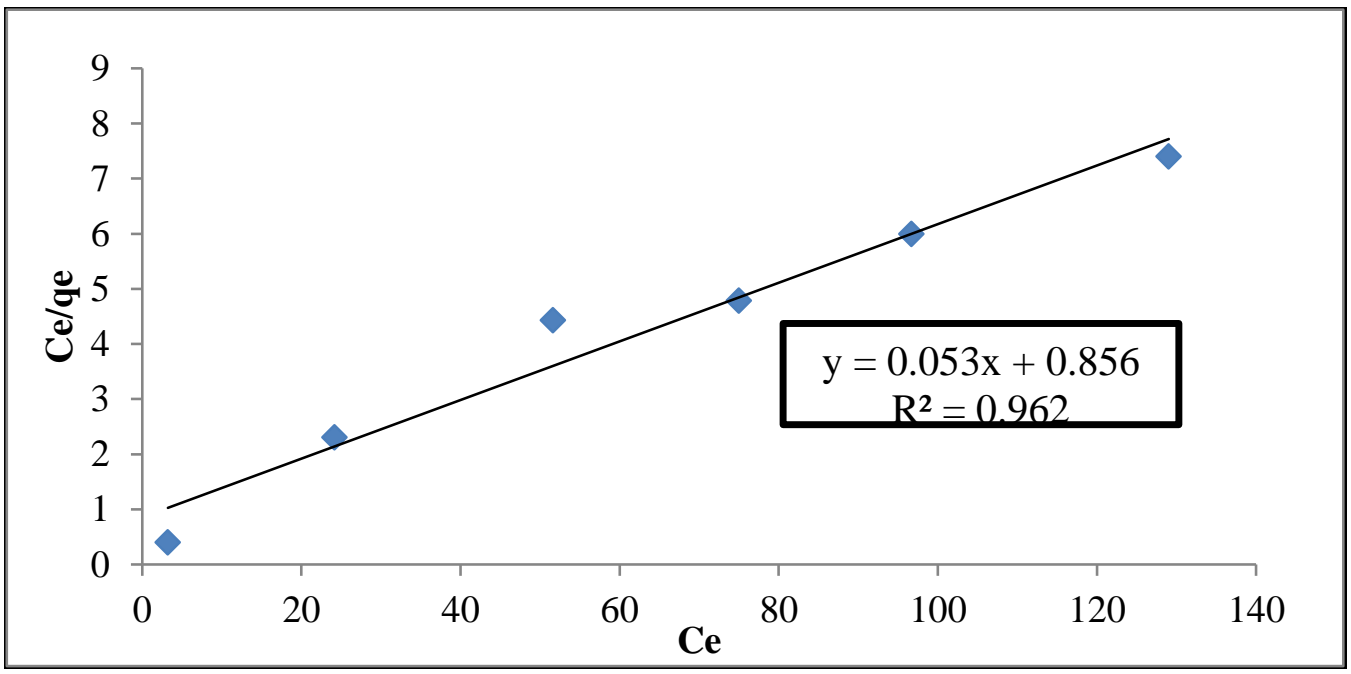

Figure 5. Langmuir isotherm for biosorption of Ni (II) ions by the fruit bark of arabica coffee (Coffea arabica).

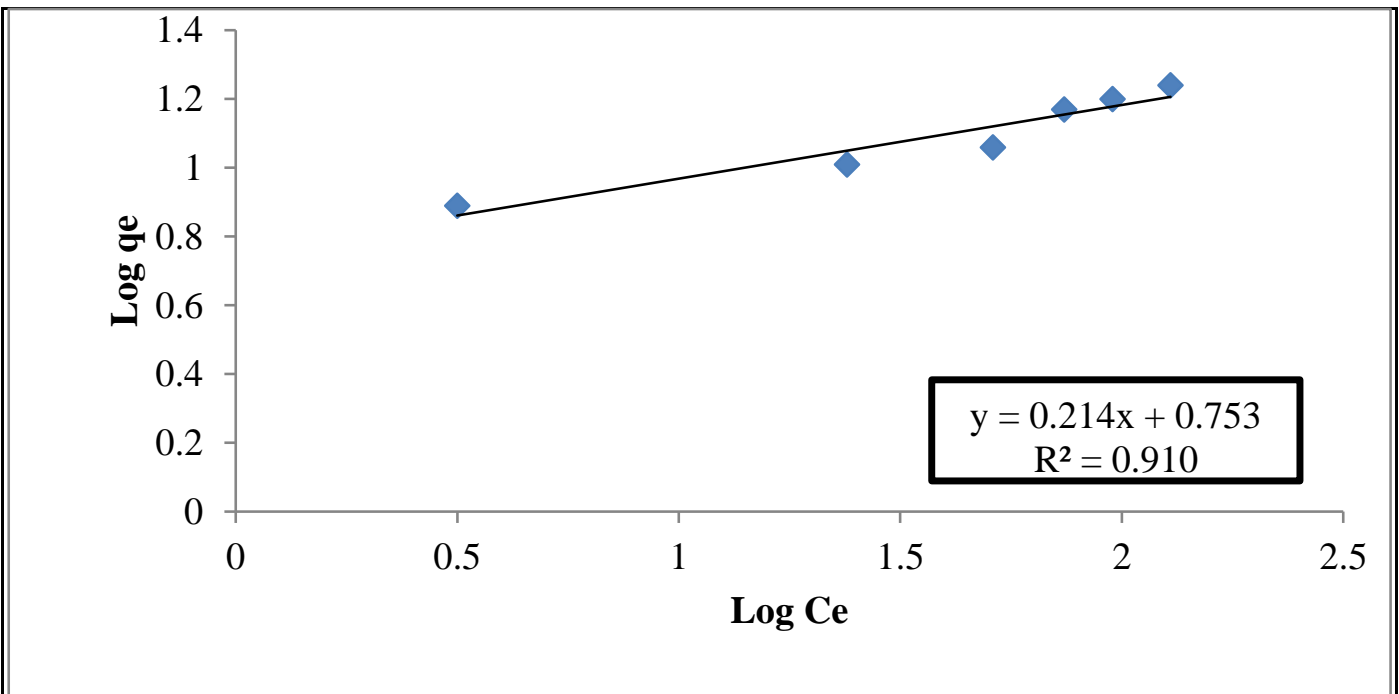

Figure 6. Isotermal Freundlich for ion $\mathrm{Ni}(\mathrm{II})$ biosorption by coffe fruit skin arabika (Coffea arabica)

The appropriate adsorption isothermal model can be seen by comparing the least squares value. Figures 5 and 6 show that the adsorption of Ni (II) ions by the skin of arabica (Coffea arabica) coffee is more in accordance with the isothermal langmuir. This can be seen from the correlation coefficient R2 with the largest value (close to 1 ), which is 0.962 while the isothermal Freundlich adsorption is R2 by 0.910 . Intercept and isothermal slope from Langmuir adsorption gave a value of biosorption capacity (Qo) of $18.86 \mathrm{mg} / \mathrm{g}$ or 0.31 $\mathrm{mmol} / \mathrm{g}$ and $\mathrm{b}$ (biosorption intensity) of $0.061 \mathrm{~L} / \mathrm{mg}$.

Langmuir isotherm assumes that the active sites found on the surface of the adsorbent are homogeneous where 
the site is active and the energy that occurs is the same, the interaction between the adsorbent and adsorbate occurs in the first layer or called monolayer on the adsorbent surface so that a strong bond between sites occurs. active with $\mathrm{Ni}$ (II)

According to Kojima and Lee (2001) in Pravasant et al (2005), different adsorbents provide different adsorption characteristics. Therefore, the suitability of isothermal adsorption depends on the biosorbent used.

Determination of Function Groups Involved in Biosorption of $\mathrm{Ni}$ (II) Metal Ions by Arabica Coffee Fruit Skin (Coffea arabica)
Determination of functional groups that play an active role in the skin of arabica coffee (Coffea arabica) is determined using FTIR. Coffee fruit skin powder before and after adsorption was analyzed using FTIR. The interaction between $\mathrm{Ni}$ (II) ions and the skin of Arabica coffee (Coffea arabica) can be seen in the spectrum of IR spectroscopy readings.

According to Pavasant, et al (2005), in comparing between samples before and after adsorption, it can be seen from the shift that is $>10 \mathrm{~cm}-1$. This shift shows the existence of a metal binding process on the surface of the sample used. Figure 7 shows the FTIR spectrum of Arabica coffee fruit peel before and after adsorption

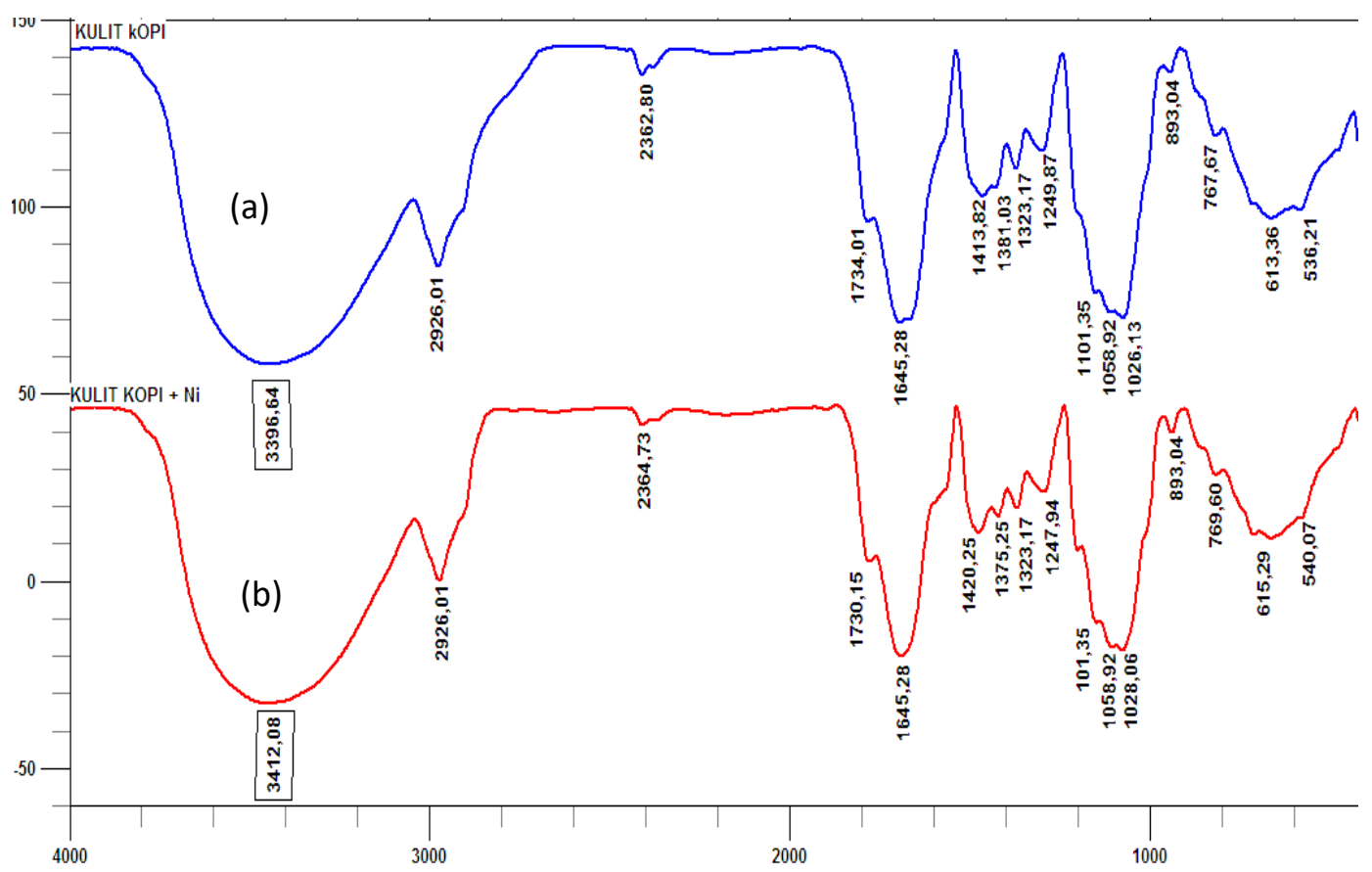

Figure 7. Spectrum of Analysis Results of FT-IR Skin Biosorbents of Arabica (Coffea arabica) Coffee Fruit (a) Before Contact with Ni (II) and (b) Ions After Contact with Ni (II) Metals

Both the FTIR spectrum images above do not show a significant difference. Characterization data of adsorbent of coffee fruit skin before and after adsorption can be shown in Table 1 . 
Table 1 Characterization of FT-IR spectra on Arabica Coffee fruit skin adsorbent before and after adsorption (Zahroh, 2010)

\begin{tabular}{cccc}
\hline IR Peak & \multicolumn{2}{c}{ Adsorption Peak (cm-1) } & \\
\cline { 2 - 3 } & Before adsorption & After Adsorption & Functional Groups \\
\hline 1 & 3396,64 & 3412,08 & -OH group bond \\
\hline 2 & 2926,01 & 2926,01 & $-\mathrm{CH}$ Vibration \\
\hline 3 & 1734,01 & 1730,15 & $\mathrm{C}=\mathrm{O}$ \\
\hline 4 & 1413,82 & 1420,25 & $\mathrm{CH}_{2}$ bend \\
\hline 5 & 1381,03 & 1375,25 & C-H \\
\hline 6 & 1249,87 & 1247,94 & C-O strech \\
\hline 7 & 767,67 & 769,60 & O-H bend \\
\hline 8 & 536,21 & 540,07 & C-C strech \\
\hline
\end{tabular}

In FTIR spectra of coffee fruit skin biomass after being interacted with $\mathrm{Ni}$ (II) as in Figure 7 (b), it can be seen that some absorption experiences a shift in wave numbers. This can be seen in the shift of wave numbers from $3396.64 \mathrm{~cm}$ 1 and 1413, $82 \mathrm{~cm}-1$. The absorption experiences a difference in the shift of a larger wave number than the other absorption.

The shift of wave number from $3396.64 \mathrm{~cm}-1$ to $3412.08 \mathrm{~cm}-1$ (stretch$\mathrm{OH})$. This shows the interaction of $\mathrm{Ni}$ (II) ions with the hydroxyl (-OH) functional groups found in the skin of Arabica coffee fruit. The wave number in the area of $2926 \mathrm{~cm}-1$ indicates the presence of $-\mathrm{CH}$ vibrations of the alkyl group of cellulose. Wave number 1413 $\mathrm{cm}-1$ shows the formation of $\mathrm{CH} 2$ in the cellulose monomer structure. It was also strengthened by changes in the formation of the $\mathrm{CH}$ group at wave number $1381.03 \mathrm{~cm}-1$.

To form a complex, the empty orbitals in $4 \mathrm{~s} 2$ undergo hybridization providing 4 orbitals namely $4 \mathrm{~s}$ and $4 \mathrm{p}$, then filled with 4 electron pairs derived from the hydroxyl group $(-\mathrm{OH})$ as ligands that occupy a $3 \mathrm{~d}$ orbital, one in $4 \mathrm{~s}$ orbitals and two $4 \mathrm{p}$ orbitals .

Based on Figure 7, the peak FTIR $(-\mathrm{OH})$ spectrum is not lost but only shifts, it can be concluded that the bond that occurs is a coordination covalent bond. Then shifting the wave number becomes larger, indicating the stronger the bond that occurs (Tannasal, 2015).

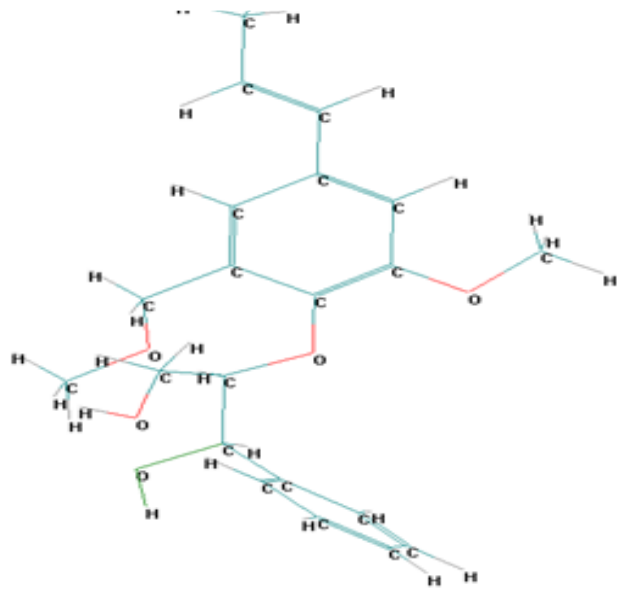

Total Energy $=74,029 \mathrm{kkal} / \mathrm{mol}$ 
Figure 8. The $-\mathrm{OH}$ hydroxyl group which is not blocked by the steric effect

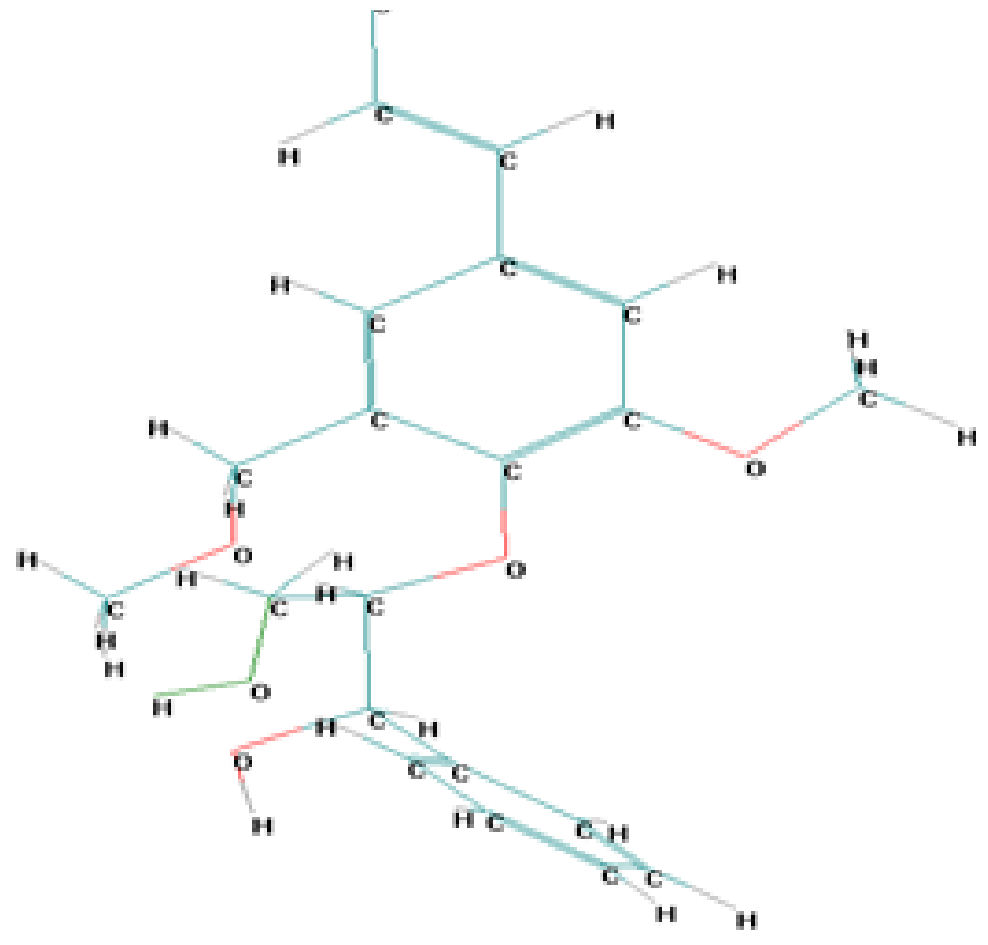

Total Energy $=104.602 \mathrm{kkal} / \mathrm{mol}$

Figure 9. Hydroxyl $-\mathrm{OH}$ group which is blocked by the steric effect

Looking at the FT-IR results in Figure 7 , it is estimated that there is a bond between the hydroxyl $(-\mathrm{OH})$ functional groups derived from lignin and cellulose with $\mathrm{Ni}$ (II) ions due to the presence of hydroxyl $(-\mathrm{OH})$ groups on cellulose and lignin which are not blocked by the effect while the steric on the hydroxyl group pectin is blocked by the presence of steric effects and also the group $(-\mathrm{OH})$ in the pectin derived from the group $(-\mathrm{COOH})$, oxygen in the group $(-\mathrm{OH})$ and in the group $(-\mathrm{CO})$ has the same ability to attract electrons due to the conjugate effect so the possibility of shifting is the group (-CO) (Tannasal, 2015). The -OH group without steric can be seen in Figure 8 and the steric obstacle in the -OH group can be seen in Figure 9. The estimated form of interaction produced can be seen in Figure 10 


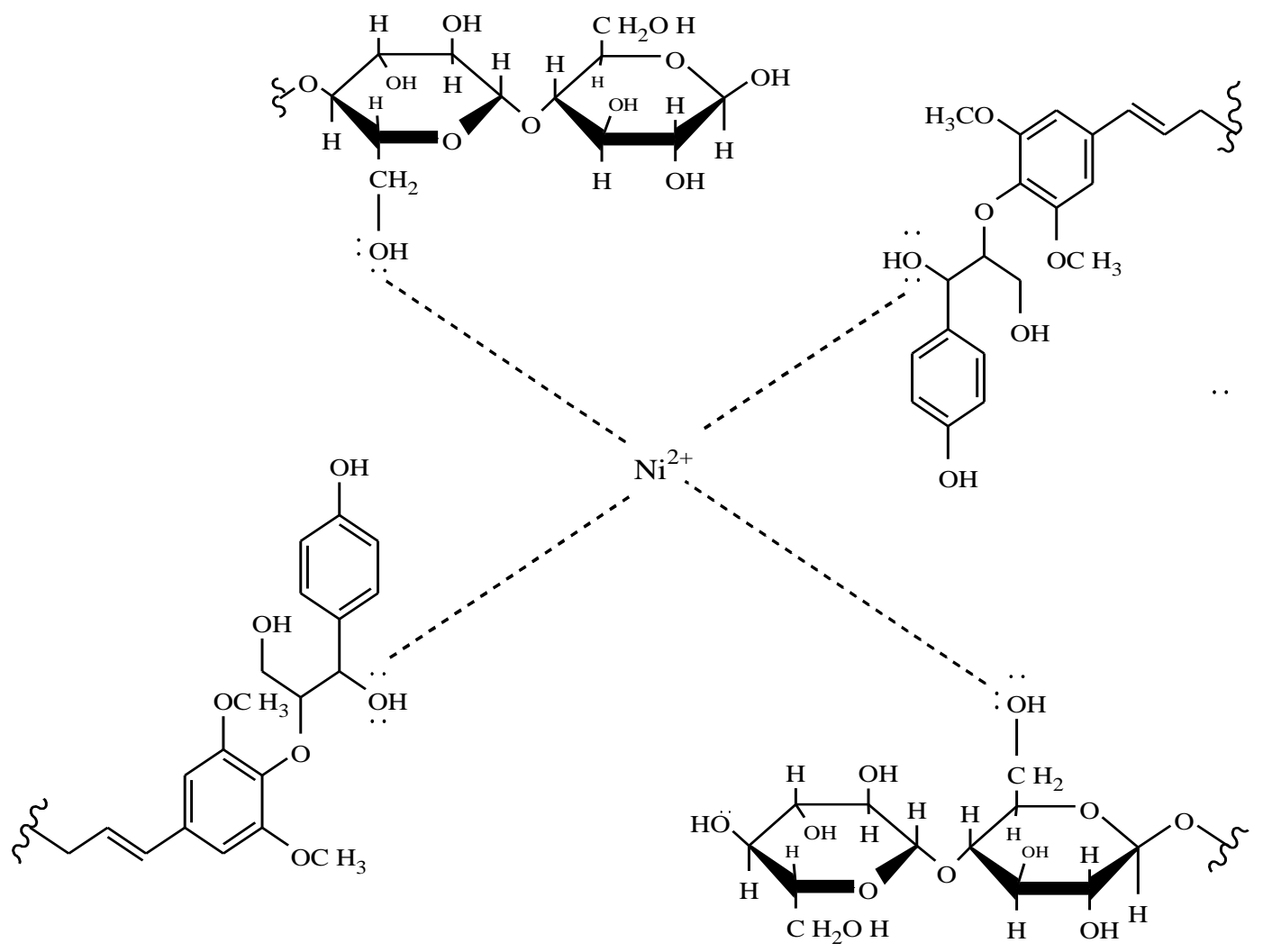

Figure 10. Form of Interaction between Ni (II) ion and Lignin and cellulose (this reaction is adopted from the reaction form between metal Cd (II) and Red Meranti Wood (La Nafie dkk.,2012).

\section{CONCLUSION}

Adsorption of $\mathrm{Ni}$ (II) ions with optimum Arabica (Coffea arabica) coffee peel powder at 120 mesh with optimum time of 50 minutes and optimum $\mathrm{pH}$ 6. Biosorption of $\mathrm{Ni}$ (II) ions by Arabica coffee fruit shells fulfills Langmuir isotherm with a Qo value of $18,86 \mathrm{mg} / \mathrm{g}$ or $0.31 \mathrm{mmol} / \mathrm{g}$. The functional group involved in biosorption of $\mathrm{Ni}$ (II) ions by the skin of Arabica coffee fruit, namely the hydroxyl group $(-\mathrm{OH})$.

\section{REFERENCES}

Abbasi, Z., dkk., 2013, Adsorptive Removal of $\mathrm{Co}^{2+}$ and $\mathrm{Ni}^{2+}$ by Peels of Banana from aqueous Solution, Universal Journal of Chemistry 1(3): 90-95.
Ahalya, N., Kanamadi, R.D., Ramachandra, T.V., 2008, Biosorption of Chromium(VI) by Tamarindus Indica Pod Shells, Journal of Environmental Science research international 1 (2): 77-81.

Ahalya, N., Ramachandra, T.V., Kanamadi, R.D., 2003, Biosorption of Heavy Metals, Research Journal of Chemistry and Environment, 4 (7).

Ahmad, F., 2009, Tingkat Pencemaran Logam Berat dalam Air Laut dan Sedimen Di Perairan Pulau Muna, Kabaena, dan Buton Sulawesi Tenggara, Makara, Sains 13 (2): 117 124.

Ahmad, A., Rafatullal, M., Sulaiman, O., Ibrahim, M.H., Chii, Y.Y., and Siddique, B.M., 2009, Removal of $\mathrm{Cu}(\mathrm{II})$ and $\mathrm{Pb}$ (II) ions from aqueous 
solutions by adsorption on sawdust of Meranti wood, Desalination, 250: 300-310.

Axtell, N.R., Sternberg, S.P.K dan Claussen, K., 2003, Lead and Nickel Removal using Microspora and Lemna minor, Bioresour. Technol, 89: 41-48.

Babarinde, A., Babalola, J.O., Ashidi, J., Adegoke, J., Osundeko, A., Nworie, C.D., Nwaeze, U.B., dan Obadina, M.S., 2013, Kinetic and Thermodynamic Parameters for The Biosorption of $\mathrm{Ni}(\mathrm{II}), \mathrm{Cr}(\mathrm{III})$, and $\mathrm{Co}$ (II) from Solutions using Cocoa (Theobroma cacao) Leaf, The Pacific J. of Sci. Tech., 14 (1): 283-294.

Borba, C.E., Guirardello, R., Sva, E.A., Veit, M.T., dan Tavares, C.R.G., 2006, Removal of Nickel (II) Ions From Aqueous Solution By Biosorption In A Fixed Bed Coloum ; Experimental And The Theoretical Break Through Curves, Biochem Eng. J., 30: 184-191.

Das, N., Karthika, P., Vimala, R., Vinodhini, V., 2008, Use of Natural Products as Biosorbent of Heavy Metals : An Overview, Natural Product Radiance $\quad 7$ (2): 133138.

Davies, F.TJ., Puryear, J.D.,Newton, R. J., Egilla, J.N.,Saraiva Grossi, J.A., 2002, Mycorrhizal Fungi Increase Chromium Uptake By Sunflower Plants: Influence on Tissue Mineral Concentration, Growth and Gas Exchang, Journal of Plant Nutrition 11 (25): 2389-2407.

Diantariani, N.P., Sudiarta, I.W., dan Elantiani, N.K., 2008, Proses Biosorpsi dan Desorpsi Ion Cr(VI) pada Biosorben Rumput Laut Euscheuma spinosium, Jurnal Kimia, 2 (1): 45-52.

Effendi, 2015, Adsorbsi Logam Ni(II) dan Pb(II) dengan Menggunakan Arang Sekam Padi yang Teraktivasi
$\mathrm{H}_{3} \mathrm{PO}_{4}$, skripsi, Fakultas Sains dan teknologi, Universitas Islam sunan Kalijaga, Yogyakarta.

Ekmekyapar, F., Ali, A., Kemal Y.B., Avni C., 2006, Biosorption of copper (II) by Non Living Lichen Biomass of Cladonia rangiformis hoffm, J. Ha. Mate. B, 137(1): 293-298.

Sayed, G., Dessouki, H., dan Ibrahim, S., 2010, Biosorption of $\mathrm{Ni}$ (II) and Cd(II) Ions from Aqueous Solution Onto Rice Straw, Chemical Science Journal, 1-11.

Sembodo, B.S.T., 2006, Model Kinetika Langmuir untuk Adsorpsi Timbal pada Abu Sekam Padi, Ekuilibrium, 5 (1): 28-33.

Shofiyani,S., dan Gusrizal, 2006, Pengaruh $\mathrm{pH}$ dan Penentuan Kapasitas Adsorpsi Logam Berat Pada Biomassa Eceng Gondok (Eichhornia crassipes), indo.J.Chem, 6 (1): 56-60.

Simanihuruk, K., dan Sirait, J., 2010, Silase Kulit Buah Kopi Sebagai Pakan Dasar Pada Kambing Boerka Sedang Tumbuh, Seminar Nasional Teknologi Peternakan dan Veteriner,: 557-566.

Soeprijanto, Elsony, A., Sulistyowati, E., 2005, Kinetika biosorpsi ion logam berat $\mathrm{Cr}(\mathrm{VI})$ menggunakan biomassa Saccharomyces cerevisiae, Jurnal teknik kimia Indonesia, 4 (1): 183-190.

Suardana, I. N., 2008, Optimalisai Daya Adsorpsi Zeolit Terhadap Ion Kromium(III), Jurnal Penelitian dan pengembangan Sains \& Humaniora, 2 (1): 17-33.

Suprihatin dan Erriek, A., 2009, Biosorpsi Logam $\mathrm{Cu}$ (II) dan $\mathrm{Cr}(\mathrm{VI}$ ) Pada Limbah Elektroplating Dengan Menggunakan

Biomasa Phanerochaete chrysosporium, Jurnal tekik Kimia, 4 (1) : 250-254.

Svehla, G., 1990, Buku Teks Analisis Anorganik Kualitatif Makro dan 
Semimikro, diterjemahkan oleh Setiono dan Hadyana, P.T Kalman Media Pustaka, Jakarta .

Tanasal, A.M., Nafie, N., dan Taba, P., 2015, Biosorpsi ion logam Cd(II) oleh kulit Buah Naga (Hylocereus polyrhizus), Skripsi, Jurusan Kimia Fakultas MIPA, Universitas Hasanuddin.

Vierra, R.H.S.F. dan Volesky, B., 2000, Biosorption: Solution To Pollution, Internal Microbiol, 3 :17-24.

Vinodhini, V., Das, N., 2009, Mechanism of $\mathrm{Cr}$ (VI) Biosorption by Nemm Sawdust, American-Eurasian Journal of Scientific Research 4 (4): 324-329.

Widaningrum, Maskiyah dan Suismono, 2007, Bahaya Kontaminasi Logam Berat Dalam Sayuran Dan Alternatif Pencegahan Pencemarannya, Buletin Teknologi Pascapanen Pertanian, 3: 16-27.
Wong, W.W., Phuah, E.T., Al-Kharkhi, A., Liong M.T., Nadiah, Rosma W.A., and Easa A.M., 2008, Biosorbent Ingradients from Durian Rind Waste, School of Industrial Technology, University Sains Malaysia, Penang.

Yesuf, Y.K., 2010, Chemical Composition and in Vitro Digestibility of Coffee Pulp and Coffee Husk Ensiled with Grass (Hyperchennia Hirta) Hay and Effective Microorganism, Tesis tidak dipublikasikan, Jimma University, College of Agriculture, and Veterinary Medicine and Centre for Development and Environment (CDE), Swiss.

Wibowo, A.Y., Putra, A., 2013, Pengaruh Ukuran Partikel Batu Apung Terhadap Kemampuan Serapan Cairan Limbah Logam Berat, Jurnal Fisika, 2(3), Issnn 2302-8491, 155-161. 